\title{
Species structure and diversity in Achanakmar-Amarkantak Biosphere reserve, Central India
}

\author{
D. K. Yadav \\ Department of Farm Forestry, Sarguja University, Ambikapur-497001 (C.G.), INDIA \\ E-mail: dheerajforestry@gmail.com \\ Received: December 05, 2015; Revised received: May 10, 2016; Accepted: July 15, 2016
}

\begin{abstract}
The present study was aimed at quantifying the species structure and diversity in AchanakmarAmarkantak Biosphere Reserve. Four sites characterized by varying vegetation attributes and representative of the region were selected. One-hectare, permanent plot was established on each of the site and enumeration was carried out by stratified random sampling techinique. The forest sites are characterized by poor species composition. $\mathrm{A}$ sum of 2440 trees representing 23 species and 17 families were encountered. Tree, sapling and seedling density $\left(\right.$ stems ha $\left.{ }^{-1}\right)$ ranged between $260-810,7500-35000$ and $25000-67500$, respectively while the basal cover $\left(\mathrm{m}^{2}\right.$ ha $\left.{ }^{1}\right)$ ranged between $9.96-41.6,0.86-5.07$ and $0.28-0.96$, respectively. Species diversity was highest on the dense site and low on medium site. Beta diversity was highest on degraded site. The presence of a large number of seedlings indicates the great potential source for future sustainable regeneration, provided by appropriate management regime to protect the forest from degradation and conserve the biodiversity.
\end{abstract}

Keywords: Composition, Permanent plot, Species diversity, Structure, Vegetation

\section{INTRODUCTION}

Biosphere Reserves (BR) are living examples of coexistence of human beings and nature. The Achanakmar-Amarkantak Biosphere Reserve is notified as the $14^{\text {th }}$ National Biosphere Reserve of India by Government of India on $30^{\text {th }}$ March, 2005. Tropical forests are characterized by high species richness, standing biomass and productivity (Jordan, 1983) and their diversity has attracted much attention in recent years (Sagar et al., 2003; Sahu et al., 2008). In most developing countries, including India, even protected forests experience extensive anthropogenic disturbance due to grazing, extraction of fuelwood and collection of nonwood forest products which contribute to the livelihood of forest dwelling populations (Singh et al., 1997; Hegde and Enters, 2000; Pattanayak et al., 2003). The degree of anthropogenic disturbance may differ in different parts of a conservation area (Kolongo et al., 2006) and it is argued that continuing biomass extraction activities may thwart the very goal of biodiversity conservation (van Schaik et al., 1997).

Over the past century virtually all ecosystems on earth have come under increasing human influence. This has been through direct contact and transformation (e.g. for farming, through hunting or the use of fire), the effects of habitat fragmentation, the production of pollutants or the substantial alteration of major biogeochemical cycles, such as the global $\mathrm{C}$, water and $\mathrm{N}$ cycles (Vitousek et al., 1997; Ramanathan et al., 2001; Galloway et al., 2002; Malhi and Wright, 2004). How- ever, for tropical forests that are far from most direct human impacts, the question as to whether these ecosystems have been substantially altered and what may be causing these changes is actively debated (Clark, 2004; Lewis et al., 2004).

Disturbances result in changes in species composition and vegetation structure. Altered disturbance regimes tend to cause marked changes in simulated forest composition and to accelerate the rate of forest response to climate change (Overpeck et al., 1990). In the dry tropical region, gradual forest destruction results in savannization. The functional importance shifts from the woody canopy to the herbaceous ground stratum where C-4 grasses predominate. This may lead to altered carbon storage/flux relationships and therefore will have implications for global carbon budget (Singh et al., 1991). Over the past 50 years, humans have converted and modified natural ecosystems more rapidly and over larger areas than in any comparable period of human history (Steffen et al., 2004). These changes have been driven by the rapidly growing demands for food, fish, freshwater, timber, fibre and fuel (Vitousek et al., 1997) and have contributed to substantial net gains in human well-being and economic development, while resulting in a substantial and largely irreversible loss of biodiversity and degradation in ecosystems and their services (Reid et al., 2005). Biodiversity is a valuable asset, which provides insurance and investment to sustain different ecosystems. India is one of the 12-mega biodiversity regions of the world sharing $8 \%$ of the world's total biodiversity. There are increas- 
ing demands of forest resources in India because majority of people are dependent on forests for livelihoods. Biodiversity in biosphere reserve is threatened due to various anthropogenic disturbances. Understanding the species composition, structure and diversity are important for assessing the forest ecosystems. There is need for conserving biodiversity of tropical deciduous forest ecosystems keeping in view their highly fragmented distribution. These forests are rich in medicinally important plants, minor forest produce and wildlife. There are only a few studies on plant diversity in forest ecosystem of Achanakmar Amarkantak Biosphere reserve. Therefore, the present investigation was carried out to study the species structure and diversity in Achanakmar-Amarkantak Biosphere Reserve, Central India.

\section{MATERIALS AND METHODS}

The present study was carried out at AchanakmarAmarkantak Biosphere Reserve. The study sites are located in $22^{\circ} 15^{\prime}-22^{\circ} 58^{\prime} \mathrm{N}$ latitude and $81^{\circ} 25^{\prime}-82^{\circ} 5^{\prime} \mathrm{E}$ longitude having an area of $3835.51 \mathrm{sq}$. $\mathrm{km}$. Climate is tropical and is influenced by monsoon conditions. The mean monthly temperature varies from $17.2^{\circ} \mathrm{C}$ (January) to $31.8^{\circ} \mathrm{C}$ (May) and the total annual rainfall average $1383 \mathrm{~mm}$, of which $85 \%$ occurs in the rainy season. The soils of the area are generally lateritic, alluvial and black cotton type, derived from granite, gneisses and basalts. The forest is seasonally dry tropical and includes extensive tracts of old growth Shorea robusta forest. Forest is classified into Northern Tropical Moist Deciduous and Southern Dry Mixed Deciduous forests (Champion and Seth, 1968). The former type predominates in the Biosphere Reserve area.

Four sites (Dense, Medium, Regenerating and Degraded) characterized by varying vegetation attributes and representative of the region's vegetation were selected. On each site one-hectare permanent plot was established and within the permanent plot ten quadrats $(10 \times 10 \mathrm{~m})$ was randomly placed for enumeration of tree species. In each quadrat, GBH (girth at breast height) of individual $(\geq 30$ $\mathrm{cm}$ girth) trees was measured. In the center of each $10 \times$ $10 \mathrm{~m}$ quadrat, a $2 \times 2 \mathrm{~m}$ area was marked for enumeration of saplings (individuals $>10 \mathrm{~cm}-<30 \mathrm{~cm}$ girth) and seedling (individuals $<10 \mathrm{~cm}$ girth but $\geq 30 \mathrm{~cm}$ height). Thus, all the individuals were measured by species and the diameter of all the individuals was recorded. Species area curve was used to determine minimal sample area which is based on quantitative variation of vegetation in terms of species number (Mullor-Dombios and Ellenberg, 1974). The vegetation data were quantitatively analysed for frequency, density and abundance (Curtis and McIntosh, 1950). An importance value was calculated as the sum total of relative frequency, relative density and relative dominance (Phillips, 1959). Species diversity parameters were determined using basal cover values.

\section{RESULTS AND DISCUSSION}

Species composition: In the present study a total of 2440 trees in all the forest sites representing 23 species and 17 families were encountered. The most diverse family was Combretaceae (3) followed by Anacardiaceae (2), Euphorbiaceae (2), Caesalpiniaceae (2), Fabaceae (2), Myrtaceae (1), Rhamnaceae (1), Sapotaceae (1) and Ebenaceae (1). The Dipterocarpaceae family was represented by 131 individuals followed by Combretaceae (39), Anacardiaceae (16) and Ebenaceae (13). In the dense forest a total of 810 stems ha $^{-1}$ representing 16 species and 13 families were encountered. The dipterocarpaceae was represented by 34 individuals followed by 14 individuals of combretaceae, 8 individuals of anacardiaceae and four individuals of euphorbiaceae, annonaceae and ebenaceae, respectively. It is evident from the data presented in the table 1 that $S$. robusta was the most dominant tree followed by $T$. tomentosa and $M$. tomentosa in tree layer. Highest density was recorded in $S$. robusta followed by $T$. tomentosa and M. tomentosa, D. melanoxylon, B. lanzan and $E$. officinalis. Lowest density was recorded in case of $S$. oleosa, C. graveolena, G. pinnata and B. racemosa. Highest basal area $\left(\mathrm{m}^{2} \mathrm{ha}^{-1}\right)$ was observed for $S$. robusta (20.54) followed by $T$. tomentosa (4.21) and $M$. tomentosa (1.42). Lowest basal area was observed for $B$. racemosa $\left(0.18 \mathrm{~m}^{2} \mathrm{ha}^{-1}\right)$. Basal area and density of individual tree species varied from $0.18 \mathrm{~m}^{2} \mathrm{ha}^{-1}$ to $20.54 \mathrm{~m}^{2} \mathrm{ha}^{-1}$ and 10 to 340 stems ha ${ }^{-1}$, respectively. $S$. robusta showed highest IVI value (123.88) followed by $T$. tomentosa (36.79) and $M$. tomentosa (17.80). The total density and basal area of dense forest was 810 stems $\mathrm{ha}^{-1}$ and $34.15 \mathrm{~m}^{2} \mathrm{ha}^{-1}$, respectively. Sapling

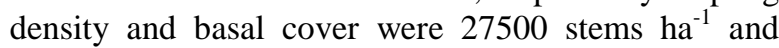
$5.02 \mathrm{~m}^{2} \mathrm{ha}^{-1}$. Among the sapling, density (20,000 stems $\left.\mathrm{ha}^{-1}\right)$ and basal cover $\left(3.46 \mathrm{~m}^{2} \mathrm{ha}^{-1}\right)$ of $M$. philipensis was highest. Among the seedling layers, seedling of $S$. robusta and D. melanoxylon was abundant.

In the regenerated forest a total of 760 stems ha $^{-1}$ representing 12 species and 8 families were encountered. The dipterocarpaceae was represented by 50 individuals followed by 14 individuals of combretaceae and 5 individuals of fabaceae. It is evident from the data presented in the table 2 that $S$. robusta was the most dominant tree followed by $T$. tomentosa and $O$. oojeinensis in tree layer. Highest density was recorded for $S$. robusta followed by $T$. tomentosa and $O$. oojeinensis. Lowest density was recorded for $C$. graveolena, $D$. melanoxylon, P. marsupium, B. lanzan and S. cumini. Highest basal area was observed for $S$. robusta followed by $T$. tomentosa and $O$. oojeinensis. Lowest basal area was recorded for $C$. graveolena. Basal area and density of individual tree species varied from 0.10 to $12.92 \mathrm{~m}^{2} \mathrm{ha}^{-1}$ and 10 to 500 stems ha ${ }^{-1,}$ respectively. $S$. robusta showed highest IVI value (161.16) followed by $T$. tomentosa (62.05) and O. oojeinensis (16.53). 
Table 1. Species structure of tropical deciduous forest on dense forest site.

\begin{tabular}{|c|c|c|c|c|}
\hline Species & $\begin{array}{c}\text { Frequency } \\
(\%)\end{array}$ & $\begin{array}{c}\text { Density } \\
\left(\text { stems ha }^{-1}\right)\end{array}$ & $\begin{array}{c}\text { BA } \\
\left(\mathbf{m}^{2} \mathbf{h a}^{-1}\right) \\
\end{array}$ & IVI \\
\hline \multicolumn{5}{|l|}{ Tree layer } \\
\hline Miliusa tomentosa (Roxb.) J.Sinclair & 40 & 40 & 1.42 & 17.80 \\
\hline Shorea robusta Gaertn F. & 100 & 340 & 20.54 & 123.88 \\
\hline Diospyros melanoxylon Roxb. & 30 & 40 & 0.72 & 13.57 \\
\hline Schleichera oleosa (Lour) Oken. & 10 & 10 & 0.35 & 4.42 \\
\hline Lannea grandis Engl. & 40 & 40 & 1.07 & 16.77 \\
\hline Cassia fistula Linn. & 20 & 20 & 0.27 & 7.61 \\
\hline Ougeinia oojeinensis (Roxb.) Hochr. & 20 & 20 & 0.65 & 8.73 \\
\hline Casearia graveolena & 10 & 10 & 0.51 & 4.90 \\
\hline Buchanania lanzan_spreng, & 30 & 40 & 0.81 & 13.84 \\
\hline Emblica officinalis Gaerth, & 30 & 40 & 0.43 & 12.73 \\
\hline Garuga pinnata Roxb. & 10 & 10 & 0.54 & 4.98 \\
\hline Lagerstroemia parviflora Roxb. & 20 & 30 & 0.60 & 9.81 \\
\hline Anogeissus latifolia_Wall. ex Bedd, & 30 & 30 & 0.56 & 11.88 \\
\hline Bauhinia racemosa Lam. & 10 & 10 & 0.18 & 3.95 \\
\hline Terminalia tomentosa Wt \& Ang. & 50 & 110 & 4.21 & 36.79 \\
\hline Madhuca indica J.F. Gmel. & 10 & 20 & 1.27 & 8.35 \\
\hline Total & 460 & 810 & 34.15 & 300.00 \\
\hline \multicolumn{5}{|l|}{ Saplings } \\
\hline Miliusa tomentosa & 20 & 5000 & 1.20 & 75.36 \\
\hline Casearia graveolena & 10 & 2500 & 0.36 & 32.99 \\
\hline Mallotus philipensis & 30 & 20000 & 3.46 & 191.65 \\
\hline Total & 60 & 27500 & 5.02 & 300.00 \\
\hline \multicolumn{5}{|l|}{ Seedlings } \\
\hline Casearia graveolena & 30 & 7500 & 0.26 & 70.67 \\
\hline Diospyros melanoxylon & 30 & 10000 & 0.04 & 41.34 \\
\hline Shorea robusta & 40 & 32500 & 0.14 & 96.13 \\
\hline Syzygium cumini & 10 & 5000 & 0.07 & 24.47 \\
\hline Buchanania lanzan & 10 & 5000 & 0.01 & 14.75 \\
\hline Anogeissus latifolia & 10 & 2500 & 0.01 & 10.96 \\
\hline Mallotus philipensis & 10 & 2500 & 0.11 & 26.72 \\
\hline Terminalia tomentosa & 10 & 2500 & 0.03 & 14.95 \\
\hline Total & 150 & 67500 & 0.67 & 300.00 \\
\hline
\end{tabular}

The total density and basal area of regenerated forest was recorded 760 stems ha $^{-1}$ and $20.47 \mathrm{~m}^{2} \mathrm{ha}^{-1}$, respectively. Density and basal cover of sapling was 35,000 stems $\mathrm{ha}^{-1}$ and 5.07. D. melanoxylon dominate the sapling layer followed by $C$. graveolena. Seedling layer density and basal area were 92,500 stems $\mathrm{ha}^{-1}$ and 0.96 $\mathrm{m}^{2} \mathrm{ha}^{-1}$. Seedling layer reveals the good regeneration of D. melanoxylon and S. robusta.

In the medium forest a total of 610 stems $^{-1}$ representing 9 species and 8 families were encountered. The dipterocarpaceae was represented by 47 individuals followed by combretaceae (5) and rhamnaceae (3). Data presented in the table 3 revealed that $S$. robusta was the most dominant among tree layer followed by T. tomentosa and Z. xylopyra. Highest density was recorded for $S$. robusta followed by $T$. tomentosa and $Z$. xylopyra. Lowest density was recorded for $L$. pariviflora, D. melanoxylon, S. cumini and A. latifolia. Highest basal area was observed in $S$. robusta followed by $T$. tomentosa and $Z$. xylopyra. Lowest basal area was observed in L. pariviflora. Basal area and density of tree species varied from 0.10 to $33.07 \mathrm{~m}^{2} \mathrm{ha}^{-1}$ and 10 to 470 stems $^{-1}$, respectively. $S$. robusta showed highest IVI value (200.02) followed by T. tomentosa
(33.94) and Z. xylopyra (19.84). The total density and basal area of medium forest was 610 stems ha $^{-1}$ and $41.60 \mathrm{~m}^{2} \mathrm{ha}^{-1}$, respectively. In sapling layer density and basal area was 20,000 stems ha ${ }^{-1}$ and $2.46 \mathrm{~m}^{2} \mathrm{ha}^{-1}$. $S$. cumini and $C$. graveolena were dominant in sapling layer. Density and basal area of seedling layer were 32,500 stems ha ${ }^{-1}$ and $0.42 \mathrm{~m}^{2} \mathrm{ha}^{-1}$. S. robusta and $C$. graveolena showed the highest regeneration on site.

In the degraded forest a total of 260 stems $^{-1} \mathrm{~s}^{-1}$ representing 7 species and 6 families were encountered. The ebenaceae family was represented by 7 individuals followed by 6 individuals of combretaceae and 5 individuals of sapotaceae. Data presented in the table 4 revealed that $D$. melanoxylon was the most dominant tree layer followed by $T$. tomentosa and $M$. indica. Highest density was recorded for $D$. melanoxylon followed by $T$. tomentosa along with $M$. indica and $B$. lanzan, respectively. Lowest density was recorded in case of A. latifolia. Highest basal area was observed for $D$. melanoxylon followed by $B$. malabaricum and T. tomentosa. Lowest basal area was recorded for $A$. latifolia. Basal area and density of individual tree species varied from 0.22 to $4.07 \mathrm{~m}^{2} \mathrm{ha}^{-1}$ and 10 to 70 stems $\mathrm{ha}^{-1}$, respectively. D. melanoxylon showed high- 
D.K. Yadav. / J. Appl. \& Nat. Sci. 8 (3): 1241 - 1248 (2016)

Table 2. Species structure of tropical deciduous forest on regenerated forest site.

\begin{tabular}{|c|c|c|c|c|}
\hline Species & $\begin{array}{c}\text { Frequency } \\
(\%)\end{array}$ & $\begin{array}{c}\text { Density } \\
\left(\text { stems ha }^{-1}\right)\end{array}$ & $\begin{array}{c}\mathbf{B A} \\
\left(\mathbf{m}^{\mathbf{2}} \mathbf{h a}^{-1}\right) \\
\end{array}$ & IVI \\
\hline \multicolumn{5}{|l|}{ Tree layer } \\
\hline Terminalia tomentosa Wt \& Ang. & 90 & 120 & 3.53 & 62.05 \\
\hline Shorea robusta Gaertn F. & 100 & 500 & 12.92 & 161.16 \\
\hline Ougeinia oojeinensis (Roxb.) Hochr. & 20 & 40 & 0.99 & 16.53 \\
\hline Casearia graveolena & 10 & 10 & 0.10 & 5.05 \\
\hline Lannea grandis Engl. & 20 & 20 & 0.55 & 11.77 \\
\hline Diospyros melanoxylon Roxb. & 10 & 10 & 0.11 & 5.10 \\
\hline Cleistenthus collinus (Roxb) Benth \& Hook. & 10 & 10 & 0.38 & 6.39 \\
\hline Terminalia chebula_ Retz. & 10 & 10 & 0.70 & 7.98 \\
\hline Buchanania lanzan_spreng, & 10 & 10 & 0.15 & 5.26 \\
\hline Anogeissus latifolia_Wall. ex Bedd, & 10 & 10 & 0.27 & 5.85 \\
\hline Pterocarpus marsupium Roxb. & 10 & 10 & 0.59 & 7.42 \\
\hline Syzygium cumini (Linn.) Skeels. & 10 & 10 & 0.18 & 5.44 \\
\hline Total & 310 & 760 & 20.47 & 300.00 \\
\hline \multicolumn{5}{|l|}{ Saplings } \\
\hline Diospyros melanoxylon & 60 & 15000 & 2.19 & 135.98 \\
\hline Casearia graveolena & 40 & 12500 & 1.55 & 99.63 \\
\hline Shorea robusta & 10 & 2500 & 0.68 & 28.90 \\
\hline Mallotus philipensis & 10 & 5000 & 0.65 & 35.48 \\
\hline Total & 120 & 35000 & 5.07 & 300.00 \\
\hline \multicolumn{5}{|l|}{ Seedlings } \\
\hline Diospyros melanoxylon & 50 & 27500 & 0.47 & 111.92 \\
\hline Shorea robusta & 40 & 40000 & 0.20 & 90.95 \\
\hline Casearia graveolena & 30 & 10000 & 0.02 & 33.09 \\
\hline Mallotus philipensis & 20 & 10000 & 0.26 & 51.72 \\
\hline Terminalia tomentosa & 10 & 5000 & 0.01 & 12.33 \\
\hline Total & 150 & 92500 & 0.96 & 300.00 \\
\hline
\end{tabular}

Table 3. Species structure of tropical deciduous forest on medium forest site.

\begin{tabular}{|c|c|c|c|c|}
\hline Species & $\begin{array}{c}\text { Frequency } \\
(\%)\end{array}$ & $\begin{array}{c}\text { Density } \\
\left(\text { stems ha }^{-1}\right)\end{array}$ & $\begin{array}{c}\text { BA } \\
\left(\mathbf{m}^{2} \mathbf{h a}^{-1}\right) \\
\end{array}$ & IVI \\
\hline \multicolumn{5}{|l|}{ Tree layer } \\
\hline Lagerstroemia parviflora Roxb. & 10 & 10 & 0.10 & 6.24 \\
\hline Shorea robusta Gaertn F. & 100 & 470 & 33.07 & 200.02 \\
\hline Careya arborea Roxb. & 20 & 20 & 0.50 & 13.18 \\
\hline Terminalia tomentosa $\mathrm{Wt} \&$ Ang. & 30 & 40 & 5.97 & 33.94 \\
\hline Diospyros melanoxylon Roxb. & 10 & 10 & 0.23 & 6.55 \\
\hline Syzygium cumini (Linn.) Skeels. & 10 & 10 & 0.44 & 7.04 \\
\hline Zizyphus xylopyra Willd, & 30 & 30 & 0.78 & 19.84 \\
\hline Lannea grandis Engl. & 10 & 10 & 0.17 & 6.39 \\
\hline Anogeissus latifolia_Wall. ex Bedd, & 10 & 10 & 0.35 & 6.82 \\
\hline Total & 230 & 610 & 41.60 & 300.00 \\
\hline \multicolumn{5}{|l|}{ Saplings } \\
\hline Syzygium cumini & 40 & 10000 & 1.08 & 151.04 \\
\hline Casearia graveolena & 20 & 7500 & 1.08 & 109.91 \\
\hline Diospyros melanoxylon & 10 & 2500 & 0.30 & 39.05 \\
\hline Total & 70 & 20000 & 2.46 & 300.00 \\
\hline \multicolumn{5}{|l|}{ Seedlings } \\
\hline Diospyros melanoxylon & 10 & 2500 & 0.02 & 29.18 \\
\hline Shorea robusta & 20 & 15000 & 0.01 & 81.83 \\
\hline Casearia graveolena & 10 & 10000 & 0.28 & 113.64 \\
\hline Syzygium cumini & 10 & 2500 & 0.03 & 31.81 \\
\hline Lagerstroemia parviflora & 10 & 2500 & 0.08 & 43.55 \\
\hline Total & 60 & 32500 & 0.42 & 300.00 \\
\hline
\end{tabular}

est value of IVI (88.81) followed by $T$. tomentosa (59.62) and $M$. indica (39.88). The total density and basal area of degraded forest were 260 stems ha $^{-1}$ and $9.96 \mathrm{~m}^{2} \mathrm{ha}^{-1}$, respectively. Density (stems $\mathrm{ha}^{-1}$ ) and basal area $\left(\mathrm{m}^{2} \mathrm{ha}^{-1}\right)$ of sapling layer on this site were
7500 and 0.86 , respectively. S. cumini was dominant in sapling layer. Seedling density (stems $\mathrm{ha}^{-1}$ ) and basal area $\left(\mathrm{m}^{2} \mathrm{ha}^{-1}\right)$ were 25000 and 0.25 , respectively. $C$. graveolena was dominant among seedling layer.

Species diversity: Species diversity parameters are summarized in the table 5. Shannon index $\left(\mathrm{H}^{\prime}\right)$ varied 
D.K. Yadav. / J. Appl. \& Nat. Sci. 8 (3): 1241 - 1248 (2016)

Table 4. Species structure of tropical deciduous forest on degraded forest site.

\begin{tabular}{|c|c|c|c|c|}
\hline$\overline{\text { Species }}$ & $\begin{array}{c}\text { Frequency } \\
(\%)\end{array}$ & $\begin{array}{c}\text { Density } \\
\left(\text { stems ha }^{-1}\right)\end{array}$ & $\begin{array}{c}\text { BA } \\
\left(\mathbf{m}^{2} \mathbf{h a}^{-1}\right) \\
\end{array}$ & IVI \\
\hline \multicolumn{5}{|l|}{ Tree layer } \\
\hline Anogeissus latifolia_Wall. ex Bedd, & 10 & 10 & 0.22 & 11.36 \\
\hline Terminalia tomentosa $\mathrm{Wt} \&$ Ang. & 50 & 50 & 1.40 & 59.62 \\
\hline Pterocarpus marsupium Roxb. & 20 & 20 & 0.57 & 23.99 \\
\hline Diospyros melanoxylon Roxb. & 40 & 70 & 4.07 & 88.81 \\
\hline Buchanania lanzan_spreng, & 30 & 40 & 0.58 & 36.96 \\
\hline Bombax malabaricum Linn. & 20 & 20 & 2.11 & 39.38 \\
\hline Madhuca indica J.F. Gmel. & 20 & 50 & 1.01 & 39.88 \\
\hline Total & 190 & 260 & 9.96 & 300.00 \\
\hline \multicolumn{5}{|l|}{ Saplings } \\
\hline Syzygium cumini & 20 & 5000 & 0.64 & 207.88 \\
\hline Casearia graveolena & 10 & 2500 & 0.22 & 92.12 \\
\hline Total & 30 & 7500 & 0.86 & 300.00 \\
\hline \multicolumn{5}{|l|}{ Seedlings } \\
\hline Zizyphus xylopyra & 10 & 2500 & 0.05 & 44.35 \\
\hline Diospyros melanoxylon & 10 & 2500 & 0.01 & 28.49 \\
\hline Casearia graveolena & 30 & 17500 & 0.22 & 200.29 \\
\hline Shorea robusta & 10 & 2500 & 0.01 & 26.86 \\
\hline Total & 60 & 25000 & 0.28 & 300.00 \\
\hline
\end{tabular}

Table 5. Diversity parameters of tropical deciduous forest on various forest site.

\begin{tabular}{lllll}
\hline Parameters & Dense & Regenerated & Medium & Degraded \\
\hline Species richness (d) & 4.2 & 3.6 & 2.14 & 3.9 \\
Shannon index (H') & 2.3 & 1.8 & 1.09 & 2.3 \\
Concentration of dominance (Cd) & 0.38 & 0.43 & 0.65 & 0.25 \\
Equitability (e) & 0.82 & 0.75 & 0.49 & 1.2 \\
Beta diversity (Bd) & 5.0 & 7.42 & 10.0 & 12.1 \\
\hline
\end{tabular}

from site to site in the study area of AchanakmarAmarkantak Biosphere Reserve and was recorded 2.3 for dense forest, 1.8 for regeneration forest, 10.9 for medium and 2.3 for degraded forest, respectively.

The values recorded for concentration of dominance $(\mathrm{Cd})$ on different forest sites were 0.38 for dense forest, 0.43 for regeneration forest, 0.65 for medium forest and 0.25 for degraded forest, respectively. Equitability (e) values were 0.82 for dense forest, 0.75 for regeneration forest, 0.49 for medium and 1.2 for degraded forest, respectively. Species richness (d) was highest in dense forest (4.2) followed by degraded forest (3.9), regeneration forest (3.6). However, the lowest value was recorded in medium forest (2.14).Beta diversity $(\beta d)$ was highest on degraded forest (12.1) followed by medium forest (10.0), regeneration forest (7.42) and the lowest value was recorded on dense forest (5.0), respectively.

The biosphere reserve is presently influenced by various biotic pressures like grazing, forest fire, illicit felling and land use change. These factors are causing great loss to forest health and biodiversity of the region. Anthropogenic disturbance cause a significant impact on regeneration of species, composition, structure, diversity, biomass and carbon storage of the tropics (Yadav and Singh, 2010; Jhariya et al., 2012; Pawar et al., 2014a \& b). The shifts in species composition in natural forest occur slowly under normal conditions but biotic interference can reduce structural and biological complexity (Jhariya et al., 2012 and 2014; Kittur et al., 2014a \& b).

The structural analysis of vegetation revealed the variation in densities and basal covers of different forest sites. Density varied between 260 and 810 stems ha -1 and basal cover between 9.96 and $41.60 \mathrm{~m}^{2} \mathrm{ha}^{-1}$. Number of tree species varied from 7 to 16 . The number of tree species, density and basal area values are comparable to other tropical forest ecosystems (Murphy and Lugo, 1986b; Singh and Singh, 1991; Sagar et al., 2003; Singh et al., 2005 and Pande, 2005; Pawar et al., 2012). Density of trees ( $\geq 30 \mathrm{~cm}$ gbh) in tropical forests ranges between 245 and 859 (Ashton, 1975 and Richards, 1996) with intermediate values of 436 stems ha ${ }^{-1}$ in Reserva Forestal de San Ramon of Costa Rica (Wattenberg and Breckle, 1995). The density values of the present study were well comparable and within the range of 255-630 stems ha ${ }^{-1}$ (Jhariya et al., 2012); 250-335 stems ha-1 (Kittur et al., 2014a); 380-880 stems ha ${ }^{-1}$ (Jhariya, 2014).

Tree basal cover in the present study varied between 9.96 and $41.60 \mathrm{~m}^{2} \mathrm{ha}^{-1}$ on four forest sites. These basal cover values were higher than the values reported for several dry tropical forest communities in Vindhyan region reported by Jha and Singh (1990) between 6.58 and $23.21 \mathrm{~m}^{2} \mathrm{ha}^{-1}$ and between 3.84 and $10.36 \mathrm{~m}^{2} \mathrm{ha}^{-1}$ by Singh and Singh (1991). These values compare with 17 to $40 \mathrm{~m}^{2} \mathrm{ha}^{-1}$ for dry tropical forest and 20 to $75 \mathrm{~m}^{2} \mathrm{ha}^{-1}$ for wet forest (Murphy and Lugo, 1986b). 
The present estimated values of basal area were well comparable and withing the range of 11.46 to $26.67 \mathrm{~m}^{2}$ ha $^{-1}$ (Pawar et al., 2014b); 11.13 to $33.54 \mathrm{~m}^{2} \mathrm{ha}^{-1}$ (Jhariya, 2014); 10.11 to $15.71 \mathrm{~m}^{2} \mathrm{ha}^{-1}$ (Jhariya et al., 2012); 12 to $20 \mathrm{~m}^{2} \mathrm{ha}^{-1}$ (Kittur et al., 2014a) reported for tropical deciduous forest of Chhattisgarh. Basal cover in a Puerto Rican sub-tropical dry forest was $19.8 \mathrm{~m}^{2} \mathrm{ha}^{-1}$ (Murphy and Lugo, 1986a). Basal cover and density varied between $12.8-13.7 \mathrm{~m}^{2} \mathrm{ha}^{-1}$ and 163 - 298 trees $\mathrm{ha}^{-1}$, respectively for sal forest in western terai of Nepal (Timilsina et al., 2007). Pande (2005) reported density for trees between 46.93 and 387.5 stems $\mathrm{ha}^{-1}$, for shrubs between 114 and 714.95 stems $\mathrm{ha}^{-1}$ and for herbs between 15905 to 102078 herbs stems $\mathrm{ha}^{-1}$ in Satpura plateau, M.P. Singh et al. (2005)

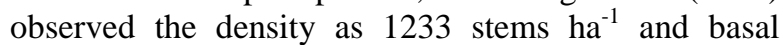
cover as $36.36 \mathrm{~m}^{2} \mathrm{ha}^{-1}$ for pure sal forest. The degraded moist deciduous forest sites represent the low density $\left(633\right.$ stems ha $\left.^{-1}\right)$ and basal cover $\left(32.82 \mathrm{~m}^{2} \mathrm{ha}^{-1}\right)$ of tree in Achanakmar wild life sanctuary, Chhattisgarh, India. Tree density in the Vindhyan region ranges between 294 and 627 stems $^{-1}$ for several dry tropical forest communities (Singh and Singh, 1991; Jha and Singh, 1990). The forest canopy was three storyed in the present forest. The dry tropical forest usually has 13 and the wet tropical forest three or more canopy strata (Murphy and Lugo, 1986b).

Deciduous forests are not considered species rich, but have a diversity of life forms. Still these forests assume unusual significance for conservation since they are the most used and threatened ecosystem, especially in India. Results of diversity parameters revealed that Shannon index (H') values in the present study ranged from 1.09 to 2.3 , equitability (e) from 0.49 to 1.2 , species richness (d) from 2.14 to 4.2, concentration of dominance $(\mathrm{Cd})$ from 0.25 to 0.65 and beta diversity $(\beta d)$ from 5.0 to 12.1 , respectively. The present study is also comparable with the diversity indices reported in different tropical forests (Singh and Singh, 1991; Pande et al., 2002; Singh et al., 2005 and Pande, 2005). The Shannon index in the present study was low (1.09 to 2.3) compared to dry Dipterocarp forest and mixed deciduous forest of Thailand (3.75 to 4.49; Kiratiprayoon et al., 1995), tropical rain forest of silent valley, India (3.8 to 4.8; Singh et al., 1984a) and of Barro Colorado Island (4.8; Knight, 1975). Tripathi et al. (2004) reported richness index from 2.25 to 3.94 in humid tropical evergreen forests of Saddle peak area of Andaman Island. Pascal et al. (1988) reported the range between 2.1 to 4.3 in different forest ecosystems in Western Ghats. Tripathi et al. (2004) reported the species diversity $(\mathrm{H})$ from 2.26 to 3.58 in tropical forests of Andaman. Panchal and Pandey (2004) observed lowest and highest value as 2.034 and 3.53, respectively in tropical forests in Gujrat and sal forest in north India.

Diversity parameters in the tropical dry forest commu- nities of the Vindhyan region (Jha, 1990) had ranges of 0.68 to 2.08 (Shannon - Wiener index), 0.75 - 1.75 (equitability), 1.62 to 7.77 (Simpson's index) and 0.13 to 4.33 (Beta diversity). Diversity in the dry forest of the Vindhyan hill as reported by Singh and Singh (1991) had ranged between 1.93 to 2.82 (Shannon Wiener index), 0.83 to 1.04 (equitability), 0.18-0.39 (Simpson's index) and 0.88 to 1.4 (Species richness), concentration of dominance from 0.18 to 0.75 and beta diversity was 3.1 for dry deciduous forests of Vindhyan region, India. Sagar and Singh (2003) reported Shannon-wiener index between 1.398 to 2.629 for dry tropical forest located along the disturbance gradient. Diversity of plants in pure sal forest was 2.82 (Shannon index), 4.76 (richness index) and 0.99 (equitability index) as reported by Singh et al. (2005). The Shannon index values of in present study were comparatively lower (3.4 to 4.8 ) than those reported by Singh et al. (1984a) for tropical rain forests of Silent valley in Western Ghats, India. De, Aparajita (2007) calculated the diversity values (0.87 - 3.89) from the corridor area of Rajaji Corbett National Parks, Uttaranchal, India. Shannon - Wiener index for tree species was $1.84-2.46,1.39$ and 0.53 for Shiwaliks, Doon Valley and outer Himalaya, respectively (Rawat and Bhainsora, 1999). The diversity values obtained in the present study were also comparable to studies conducted in the Corbett National Park (Singh et al., 1995), where the values ranged from 1.79 to 3.64. Beta diversity ranged from 5.0 to 12.1 , a low index values as compared to those reported by others for communities occurring in different environmental gradients (Adhikari et al., 1991). The beta diversity was found to be highest for degraded forests and lowest for dense forest.

\section{Conclusion}

The study suggests that the high level of disturbance due to over exploitation of trees for timber and firewood had critically affected the regeneration status, species structure and diversity of the Biosphere reserve area. This is evidenced by the very low density, diversity and basal area on degraded site. The forest has lost its climax vegetation due to anthropogenic pressure which if increased, may retrogress the succession into a degraded community. Despite the escalating exploitation of the forest, the phytosociological analysis of the Achanakmar Amarkantak Biosphere Reserve indicates that this forest is an extremely important ecosystem by the virtue of high richness and diversity of tree species. The presence of a large number of seedlings in the dense and regenerated sites indicates the great potential source for sustainable regeneration of the forest, provided by appropriate management regime to protect the forest from degradation and conserve the biodiversity. 


\section{REFERENCES}

Adhikari, B.S., Rikhari, H.C., Rawat, Y.S. and Singh, S.P. (1991). High altitude forest: composition, diversity and profile structure in a part of Kumaun Himalaya. Tropical Ecology, 32(1): 86-97.

Ashton, D.H. (1975). Studies of litter in Eucalyptus regnans forests. Aust. J. Bot., 23: 413-433.

Champion, H.G. and Seth, S.K. (1968). A Revised Survey of the Forest Types of India. Government of India Publications, New Delhi, 404p.Clark, D.A. (2004). Sources or sinks? The responses of tropical forests to current and future climate and atmospheric composition. Phil. Trans. R. Soc. Lond. B, 359: 477- 491.

Curtis, J.T. and McIntosh, R.P. (1950). The interrelations of certain analytic and synthetic phytosociological characters. Ecology, 31: 434-455.

De, Aparajita. (2007). Patterns of plant species diversity in the forest corridor of Rajaji Corbett National Parks, Uttaranchal, India. Current Science, 92(1): 90-93.

Galloway, J.N., Cowling, E.B., Seitzinger, S.P. and Socolow, R.H. (2002). Reactive nitrogen: too much of a good thing? Ambio, 31: 60-63.

Hegde, R. and Enters, T. (2000). Forest products and household economy: a case study from Mudumalai Wildlife Sanctuary, Southern India. Environmental Conservation, (27): 250-259.

Jha, C.S. (1990). Land use and vegetation analysis of dry tropical forest region. Ph.D. Thesis, Banaras Hindu University, Varanasi, India.

Jha, C.S. and Singh, J.S. (1990). Composition and dynamics of dry tropical forest in relation to soil texture. Journal of Vegetation Science, 1: 609-614.

Jhariya, M.K., Bargali, S.S., Swamy, S.L. and Kittur, B. (2012). Vegetational structure, diversity and fuel load in fire affected areas of Tropical Dry Deciduous forests in Chhattisgarh. Vegetos, 25(1): 210-224.

Jhariya, M.K. (2014). Effect of forest fire on microbial biomass, storage and sequestration of carbon in a tropical deciduous forest of Chhattisgarh. Ph.D. Thesis I.G.K.V. Raipur (C.G.), pp. 259.

Jhariya, M.K., Bargali, S.S., Swamy, S.L., Kittur, B., Bargali, K. and Pawar, G.V. (2014). Impact of forest fire on biomass and carbon storage pattern of tropical deciduous forests in Bhoramdeo wildlife sanctuary, Chhattisgarh. International Journal of Ecology and Environmental Sciences, 40(1): 57-74.

Jordan, C.F. (1983). Productivity of tropical rain forest ecosystems and the implications for their use as future wood and energy sources. In: Golley, F.B. (ed.) Ecosystems of the World. Tropical Rain Forest Ecosystems, pp. 117-136. Elsevier, Amsterdam, NL.

Kiratiprayoon, S., Luangiame, J., Damrongthai, P. and Tarumatsawas, M. (1995). Species diversity of the second growth at Nago Demonstration Forest, Lampang Provinance. pp. 237-245. In: T.J.B. Boyle and B. Boontawee (eds.) Measuring and Monitoring Biodiversity in Tropical and Temperate Forests. Centre for International Forestry Research, Bogor, Indonesia.

Kittur, B., Swamy, S.L., Bargali, S.S. and Jhariya, M.K. (2014a). Wildland Fires and Moist Deciduous Forests of Chhattisgarh, India: Divergent Component Assessment. Journal of Forestry Research, 25(4): 857-866.

Kittur, B., Jhariya, M.K. and Lal, C. (2014b). Is the forest fire can affect the regeneration and species diversity. Ecology, Environment and Conservation, 20(3): 989994.

Knight, D.H. (1975). A phyto-sociological analysis of species rich tropical forest on Barro-Colorado Island: $\mathrm{Pa}$ nama. Ecological Monograph, 45: 259- 289.Kolongo, T.S.D., Decocq, G., Yao, C.Y.A., Blom, E.C. and Van Rompaey, R.S.A.R. (2006). Plant species diversity in the southern part of the Tai National Park (Côte d'Ivoire). Biodiversity and Conservation, (15): 21232142.

Lewis, S.L., Malhi, Y. and Phillips, O.L. (2004). Fingerprinting the impacts of global change on tropical forests. Phil. Trans. R. Soc. B, 359: 437-462.

Malhi, Y. and Wright, J. (2004). Spatial patterns and recent trends in the climate of tropical rainforest regions. Phil. Trans. R. Soc. Lond. B, 359: 311-329.

Mullor-Dombois, D and Ellenberg, H. (1974). Aims and Method of Vegetation Ecology. John Wiley and Sons, New York, USA.

Murphy, P.G. and Lugo, A.E. (1986a). Structure and biomass of a subtropical dry forest in Puerto Rico. Biotropica, 18: 89-96.

Murphy, P.G. and Lugo, A.E. (1986b). Ecology of tropical dry forest. Annual Review of Ecology and Systematics, 17: 67-88.

Overpeck, J.T., Rind, D. and Goldberg, R. (1990). Climate induced changes in forest disturbance and vegetation. Nature, 343: 51-53.

Panchal, N.S. and Pandey, A.N. (2004). Analysis of vegetation of Rampara forest in Saurashtra region of Gujrat state of India. Tropical Ecology, 45(2): 223-231.

Pande P.K., Negi, J.D.S. and Sharma, S.L. (2002). Plant species diversity composition, gradient analysis and regeneration behaviour of some tree species in a moist temperate Western Himalayan forest ecosystem. Indian Forester, 128(8): 869-885.

Pande, P.K. (2005). Ecological assessment of vegetation in JFM adapted village forest in Satpura plateau, M.P. Indian Forester, 131(1): 97-106.

Pascal, J.P., Ramesh, B.R. and Bourgeon, G. (1988). The rain forests of the Karnataka plate (India): Structure and floristic composition trends in the change due to their exploitation. Tropical Ecology, 29(2): 9-23.

Pattanayak, S., Sills, E.O., Mehta, A.D. and Kramer, R.A. (2003). Local uses of parks: uncovering patterns of household production from forests of Siberut, Indonesia. Conservation and Society, (1): 209-222.

Pawar, G.V., Singh, L., Jhariya, M.K. and Sahu, K.P. (2012). Regeneration status in relation to anthropogenic disturbance in tropical deciduous forest of Chhattisgarh. The Ecoscan, (Special Issue) 1: 281-285.

Pawar, G.V., Singh, L., Jhariya, M.K. and Sahu, K.P. (2014a). Effect of Anthropogenic Disturbances on Biomass and Carbon Storage Potential of a Dry Tropical Forest in India. Journal of Applied and Natural Science, 6(2): 383-392.

Pawar, G.V., Singh, L., Jhariya, M.K. and Sahu, K.P. (2014b). Assessment of Diversity along the Disturbance Gradient in Dry Tropics of Chhattisgarh, India. The Ecoscan, 8(3\&4): 225-233.

Phillips, E.A. (1959). Methods of Vegetation Study. Henry Holt and Co., London. pp. 105.

Ramanathan, V., Crutzen, P.J., Kiehl, J.T. and Rosenfeld, D. 
(2001). Atmosphere-aerosols, climate, and the hydrological cycle. Science, 294: 2119-2124.

Rawat, G.S. and Bhainsora, N.S. (1999). Woody vegetation of Siwaliks and outer Himalaya in north-western India. Tropical Ecology, 40: 119-128.

Reid, W.V., Mooney, H.A., Cropper, A., Capistrano, D., Carpenter, S.R., Chopra, K., Dasgupta, P., Dietz, T., Duraiappah, A.K., Hassan, R., Kasperson, R., Leemans, R., May, R.M., McMichael, A.J., Pingali, P., Samper, C., Scholes, R., Watson, R.T., Zakri, A.H., Shidong, Z., Ash, N.J., Bennett, E., Kumar, P., Lee, M.J., RaudseppHearne, C., Simons, H., Thonell, J. and Zurek, M.B. (2005). Ecosystems and Human Well-being: Synthesis. Island Press, Washington, District of Columbia, $155 \mathrm{pp}$.

Richards, P.W. (1996). The Tropical Rainforest. $2^{\text {nd }}$ ed. Cambridge Univ. Press, Cambridge.

Sagar, R. and Singh, J.S. (2003). Predominant phenotypic traits of disturbed tropical dry deciduous forest vegetation in northern India. Community Ecology, 4: 63-71.

Sagar, R., Raghubanshi, A.S. and Singh, J.S. (2003). Tree species composition, disturbance and diversity along a disturbance gradient in dry tropical forest region of India. Forest Ecology and Management, 186: 61-71.

Sahu, P.K., Sagar, R. and Singh, J.S. (2008). Tropical forest structure and diversity in relation to altitude and disturbance in a Biosphere Reserve in central India. Applied Vegetation Science, 11: 461-470.

Singh, A., Reddy, V.S. and Singh, J.S. (1995). Analysis of woody vegetation of Corbett National Park India. Vegetatio, 120: 69-79.

Singh, J.S., Singh, S.P., Saxena, A.K. and Rawat, Y.S. (1984a). The forest vegetation of Silent valley, India. Tropical Rainforest. The Leed symposium, pp.25-52.

Singh, J.S., Singh, K.P. and Agrawal, M. (1991). Environmental degradation of the Obra-Renukot-Singrauli area, India and its impact on natural and derived ecosystems. Environmentalist, 11: 171-180.

Singh, L. and Singh, J.S. (1991). Species structure, dry mater dynamics and carbon flux of a dry tropical forest in India. Annals of Botany, 68: 263-273.
Singh, L., Sharma, B., Agrawal, R. and Puri, S. (2005). Diversity and dominance of Sal dominated tropical moist deciduous forest in Achanakmar Wildlife Sanctuary. Bulletin of the National Institute of Ecology, 15: 1-9.

Singh, S.P., Rawat, Y.S. and Garkoti, S.C. (1997). Failure of brown oak (Quercus semicarpifolia) to regenerate in the Central Himalaya: a case of environmental semisurprise. Current Science, (73): 371-374.

Steffen, W., Sanderson, A., Tyson, P.D., Jäger, J., Matson, P.A., Moore, B., Oldfield, F., Richardson, K., Schellnhuber, H.J., Turner II, B.L. and Wasson, R.J. (2004). Global Change and the Earth System: A Planet Under Pressure. Springer, Berlin, 336 pp.

Timilsina, N., Ross, M.S. and Heinen, J.T. (2007). A community analysis of sal (Shorea robusta) forests in the western Terai of Nepal. Forest Ecology and Management, 241: 223-234

Tripathi, O.P., Pandey, H.N. and Tripathi R.S. (2004). Distribution, community characteristics and tree population structure of sub tropical pine forest of Meghalaya, Northeast India. International Journal of Ecology and Environmental Science, 30: 207-214.

van Schaik, C.P., Terborgh, J. and Dugelby, B. (1997). The silent crisis: the state of rain forest nature preserves. In: Kramer, R. van Schaik, C. \& Johnson, J. (eds.) Last stand: Protected Areas and the Defense of Tropical Biodiversity, pp. 64-89. Oxford University Press, New York, NY, US.

Vitousek, P.M., Mooney, H.A., Lubchenco, J. and Melillo, J.M. (1997). Human domination of earth's ecosystems. Science, 277: 494-499.

Wattenberg, I. and Breckle, S.W. (1995). Tree species diversity of a premontane rain forest in the Cordillera de Tilaran, Costa Rica. Ecotropica, 1: 21-30.

Yadav, D.K. and Singh, L. (2010). Community structure and floristic diversity of tree stratum of deciduous forest of Achanakmar-Amarkantak Biosphere Reserve. Indian Forester, 136(6): 725-735. 